\title{
News about Tap and Bottled Water: Can This Influence People's Choices?
}

\author{
Josiane T. M. Queiroz ${ }^{1 *}$, Mark W. Rosenberg ${ }^{2}$, Léo Heller ${ }^{1}$, Andréa L. M. Zhouri ${ }^{3}$, Sara R. Silva ${ }^{4}$ \\ ${ }^{1}$ Department of Environmental and Sanitary Engineering, Federal University, Minas Gerais, Brazil; ${ }^{2}$ Department of Geography, \\ Queen's University, Kingston, Canada; ${ }^{3}$ Department of Sociology and Anthropology, Federal University, Minas Gerais, Brazil; \\ ${ }^{4}$ Department of Environmental Technology, Federal Institute, Espírito Santo, Brazil. \\ Email: *josiane.matosqueiroz@yahoo.com.br
}

Received February $7^{\text {th }}, 2012$; revised March $6^{\text {th }}, 2012$; accepted April $2^{\text {nd }}, 2012$

\begin{abstract}
The pursuit of alternative safe water has increased dramatically the world trade in bottled water. Events happened in Canada which changed the population's perception about the quality of tap water, despite all government efforts. Media has an important role to pass on information because there is value judgment in its reports. As a result, this study aims to present recent data from two Canadian newspapers of national circulation, which refer to tap water and bottled water. It used quantitative and qualitative data for this analysis. The study concludes that the media, taken into consideration, provides its readers with important information, but the information can also be ambiguous. Nevertheless, it arouses interest in further research about this subject matter and about protecting water resources.
\end{abstract}

Keywords: Tap Water; Bottled Water; News Reports; Water Protection

\section{Introduction}

The impacts of environmental pollution, demands and offers of fresh water as well as the occurrence of outbreaks of waterborne diseases have been warnings for people about the quality of drinking water and its health implications. These concerns have led people to seek alternatives to the use of tap water; either through the use of some sort of home care system, the purchase of bottled water or others means [1-3].

The consumption of bottled water is a subject of research in several areas of knowledge and it is considered a worldwide phenomenon with repercussions in social, economic, medical and environmental areas. This happens even in countries where water is available and where the tap water is considered good enough for consumption [4-6].

According to Statistic Canada [7], Canadian consumption of bottled water increased by 150\% between 1999 and 2005 and three out of 10 households consume bottled water in their homes $[8,9]$ because of its organoleptic properties, health issues, convenience and cost $[10,11]$.

The population often imagines that bottled water is a pure and safe product, which is not necessarily true. More importantly, the scientific community is concerned about bottled water quality. Bottled waters marketed in

${ }^{*}$ Corresponding author. several countries have been studied for bacteriological contamination and investigated for the presence of chemical compounds and radioactivity [12-27].

In general, Canadians used to have a high level confidence in the quality of tap water. However, high profile events regarding the contamination of tap water took place in Canada; as what happened in Walkerton, Ontario -where seven people died and thousands more became ill; Saskatchewan, North Battleford-where thousands of people became ill; and Kashechewan, Ontario - an aboriginal community, where all residents were evacuated, helped to change this perception. In the specific literature, there are several papers in both academic journals and in the general media about these events that have generated considerable interest on the causes and consequences of contaminated tap water. Hundreds of advisories about boiling water before consuming it are issued all over the country each year and also as a result this raises concerns about the general safety of drinking water. Such advisories induce people to use bottled water while inspiring a culture of distrust in tap water. Such episodes have put pressure on Canadian government authorities to meet their responsibilities in providing high quality water for the population as well as the need for updates in current regulations [28-31].

On the other hand, since 2006 sales of bottled water have been discouraged or even prohibited in public agen- 
cies and universities in some Canadian cities with the intention of forcing the consumer to have or regain confidence in the quality of tap water [32,33].

Jones et al. [8] reported that participants in their study mentioned media and marketing as channels that can either inform or confuse consumers. The Jones study quotes as an example a participant who found an article stating that bottled water has equal quality to tap water and another stating that the standards for municipal tap water are higher than the ones imposed to bottled water.

The information in the media and in marketing strategies used by bottled water companies are an influential factor for the consumption of bottled water instead of tap water [34-39].

Doria [40] reported a series of papers that show how consumers seek and receive information on water supply as well as how sources of information depend on several factors. The author notes that in U.S. cities, $63 \%$ of the population use newspapers as a source of information while in France the percentage is 33\%.

According to Dittrich [41] the information released by the print media is deliberative, it informs and discusses the issues for the reader to decide, it is demonstrative because, at least implicitly, is ready to praise or blame and, finally, it is judiciary because it is prompt to defend a particular cause but does not play the role of judge, convicting or acquitting.

Based on this context in which the press exercises effective influence on the user's choice concerning water consumption, this study presents data from the print media, represented by Canadian newspapers on issues related to the consumption of tap water and bottled water. It aims to highlight the information provided to the readers and how these can influence or confuse the public regarding their choice of the kind of water consumed. Quantitative and qualitative data were used to discuss the results.

\section{Methodology}

Reports from two Canadian newspapers with representative national circulation were investigated, The Globe and Mail-TGM and The National Post-TNP. Both newspapers had articles about tap water and bottled water. The reports were accessed from a digital database provided by the library at Queen's University, Canada.

Initially, searches were carried out with the words "bottled water" and "tap water", resulting over 3000 news reports found in total.

Reading all the news reports was the first step to screen the material used. This enabled the identification of the reports that dealt directly with the issue of interest to this research. The reports selected accounted for 199 reports published from 1994 through October 2009 in the newspaper TGM and 97 reports published from 1998 (when the newspaper began its operations) through October 2009 in the newspaper TNP or a total of 296 reports. It should be stressed here that news reports dealing exclusively with the Walkerton incident, which until today has major repercussions, were selected to be read, but were not included in the analysis. This episode attracted media interest and motivated an increasing number of reports on tap water and bottled water.

The articles were divided into three categories, listed below:

1) regarding only tap water;

2) regarding only bottled water;

3) regarding aspects from both tap and bottled water;

The categories 1 and 2 were evaluated in a quantitative and descriptive way, while category 3 was evaluated with the use of Discourse Collective Subject-DCS strategy, comprising a qualitative analysis starting in 2006.

DCS consists of a discourse production modality obtained from oral testimony, through individual interviews or groups with a particular focus or in any discursive manifestation that can be found in texts and written documents. Structurally, DCS is organized by designating text as a central idea (CI), and DCS, itself [42].

$\mathrm{CI}$ is the linguistic expression that reveals and describes in a succinct, accurate and as reliable as possible way, each one of the speeches investigated. There is not an interpretation, but a description of the meaning of a statement or set of statements, which will later give birth to the DCS [42].

To develop the DCS, speeches were taken in their raw state, in other words, exactly as they were presented in the newspapers reports. These were subjected to an initial analytical work of decomposition, which consisted in using the methodological approaches presented in each one of the speeches and where we pursued the discursive reconstitution of social representation [42].

\section{Results and Discussion}

\subsection{Category 1}

For category 1, 134 reports were selected regarding only issues related to tap water. The reports were categorized according to the similarity of themes. Table 1 shows the number of reports selected and grouped by themes.

It was observed that the concern about issues of tap water contamination/sensory issues and advisories to boil water constituted a significant number (55\%) of news reports in relation to the total number of reports. Another point to highlight is the number of news reports concerning standards and legislation, focusing on the need for constant monitoring and adjustments, as other authors Holme [28] and Bakker [29], Johns et al. [30] and Rosenberg had previously identified [31]. 
Table 1. Number of reports published in TGM and TNP regarding tap water.

\begin{tabular}{lc}
\hline \multicolumn{1}{c}{ Subject matter } & n. reports \\
\hline Chemical or bacteriological contamination/taste and odor & 47 \\
Advisory to boil water & 27 \\
Standards/legislation/management & 22 \\
Water supply in indigenous communities & 17 \\
Water scarcity/high demand/preservation & 16 \\
Lack of trust in tap water/alternative systems to tap water & 4 \\
Tap water taste contest & 1 \\
\hline
\end{tabular}

The reports on water supply in indigenous communities have in general motivated many complaints. The articles discuss the failed sanitation systems in these areas, constant claims from the Indigenous populations affected, and the failure of governments to respond.

Reports about possible areas of water scarcity and high per capita consumption in Canada presented various ideas about relevant current issues to Canadians such as: water rights for large non-agricultural enterprises and re-evaluation of water consumption habits to seek conservation, among others. An important issue also addressed in the news reports is about the rates of pollution of water resources in Canada, mainly regarding the Great Lakes.

Data on how much confidence people have in tap water can be drawn from the reports: half of the Canadian population has no confidence in tap water and restoring confidence after the Walkerton incident has taken time despite all governmental efforts and investments.

Figure 1 presents a graph with the numbers of annual reports on the theme of this category.

It was observed that the reports produced in 2000 and 2001 were influenced by the events in Walkerton and Saskatchewan and by a national alert calling for proper control, monitoring and qualifications of professionals working in Canadian water treatment systems. Johns and Rasmussen [43] claim that the institutional arrangements for the management of water in Canada are complex and involve a large array of federal government departments, multiple provincial and territorial government departments and agencies, local governments and authorities, and a number of Aboriginal band governments. On top of this, Canada also has numerous bilateral agreements with the United States.

Starting in 2005, with what happened in Kashechewan, articles on tap water became more frequent with great eagerness to inform the public about what is happening in the country.

\subsection{Category 2}

For the second category 42 reports were selected. Table $\mathbf{2}$ presents the issues addressed in that category and their frequency.

When it comes to bottled water, the reports showed a great diversity of subject matter. It should be pointed out here that news reports regarding regulations or the lack of them prevailed as Barlow and Clarke had stated already [34]. One explanation is that bottled water is among the fastest growing industries and subject to few regulations by governments around the world.

Studies and reports from Barlow and Clarke [34], Barlow [44], Shiva [45], UNDP [46], Herráiz, [47] ALMG [48], present reports on how over-exploitation of aquifers can cause socio-environmental damage around the world, in countries like India, USA, Mexico, Brazil, Pakistan and African countries. The news reports also present an alert to Canadian citizens to remain vigilant showing examples of prohibitions and restrictions in several Canadian provinces.

Another important issue is the fetish some packages strike with consumers. However, Ferrier [4] states that filling companies do not only sell a liquid to a thirsty consumer, but rather a container which is much more expensive than the content and adds: "At least $90 \%$ of the actual cost of a bottle in a retail market is due to factors other than the water itself, as for example, packaging, transportation, marketing and distribution." There is a

Table 2. Number of reports published by typology, in the newspapers TGM and TNP regarding bottled water.

\begin{tabular}{lc}
\hline \multicolumn{1}{c}{ Subject matter } & n. reports \\
\hline Regulations or lack of regulations & 9 \\
$\begin{array}{l}\text { Aquifer over-exploitation/prohibitions and restrictions on } \\
\text { exploitation }\end{array}$ & 5 \\
Packaging fetish & 5 \\
$\begin{array}{l}\text { Discussions about the use of bottled water } \\
\text { Consumers of bottled water }\end{array}$ & 5 \\
$\begin{array}{l}\text { Valuable resources to export and Canada does not receive a } \\
\text { fair price }\end{array}$ & 3 \\
$\begin{array}{l}\text { Filling companies work without sustainability } \\
\text { Contract between filling companies and universities }\end{array}$ & 2 \\
Millennium Bug makes sales increase & 1 \\
Sales growth after Walkerton & 1 \\
Types of bottled water & 1 \\
Lixiviation of chemicals in packaging & 1 \\
Plastic volume reduction in packaging & 1 \\
$\begin{array}{l}\text { Bottled waters presenting problems which are not aired to } \\
\text { the public }\end{array}$ & 1 \\
Taste tests & 1 \\
\hline Sommeliers turning water into wine & 1 \\
\hline
\end{tabular}




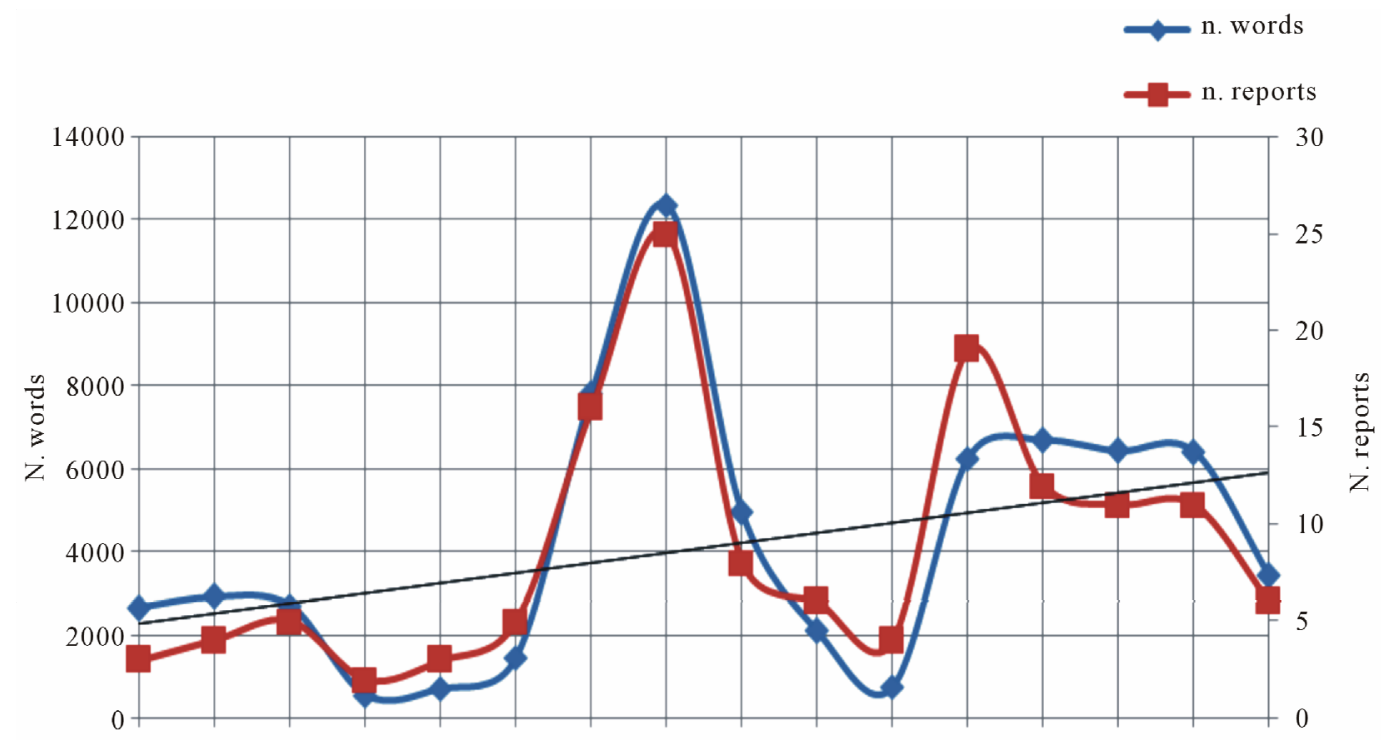

1994199519961997199819992000200120022003200420052006200720082009

year

Figure 1. Record of the number of reports published in the newspapers TGM and TNP, per year, regarding tap water.

vast array of types of packaging today: packaging studded with crystals, with gold or silver caps, targeting specific audiences, with design and signature of famous designers, in other words, anything capable of creating loyal consumers through the achievement of a desire, ignoring that the real value is in the package: clean water.

The other news reports are concerned with subjects selected from different points of view that are for or against the use of bottled water. Some may be considered as formal complaints and alerts about water exploitation, filling companies acting without sustainability, exclusive contracts with transnational companies, chemical lixiviation from water containers, and problems with bottled water in which the general public is not informed.

Figure 2 shows the number of selected annual news reports with a total of 42 from 1997 through 2009.

It was observed that in 1999, 2006 and 2008 the newspapers had a great number of news reports on this topic. This happened possibly because of the increasing consumption of bottled water since 1999, as Statistic Canada reported [7], sparked media attention. Starting in 2006, campaigns were launched throughout the country aiming to reduce the consumption of bottled water. In 2008, news reports presented topics concerning several aspects of bottled water consumption-from exploitation to the fetish caused by packaging.

\subsection{Category 3}

As described previously in the methodology, this category was analyzed with the use of DCS. A total of 52 news reports dating from 1994 through October 2009 were compiled. For this more intensive analysis using qualitative methods only reports starting in 2006 were included. This reduced the total to 32 news reports. The decision to start with 2006 was also made because there was a great concentration of articles dealing with with water in this particular year. The CI and its discourse are presented below.

\subsubsection{CI $1^{-}$Promotion of Banned and Free Zones of Bottled Water Use for Tap Water}

"According to the Council of Canadians, 27 municipalities across the country are phasing out or restricting the sale and purchase of bottled water in municipal buildings and at city events. Some churches in Canada have started to urge congregants to boycott bottled water, citing ethical, theological and social justice reasons. The Toronto's public school board is looking at banning the sale of water in plastic bottles in its 560 schools, and events in an effort to promote tap water they contend is a better choice. The University of Winnipeg says the first campus in Canada to ban bottled water sales. Plastic water bottles are increasingly being singled out as an unnecessary extravagance that consumes excessive resources, particularly considering most Canadian cities have safe municipal drinking supplies."

The proportion of news reports of the CI (11/32) is according to what the authors Hickman [32] and Marshall [33] stressed on the banning of bottled water in Canada. It is known that the mayors of San Francisco, Los Angeles, Salt Lake City, Santa Barbara, Seattle and New York, also eliminated the use of bottled water in their public offices [49]. 


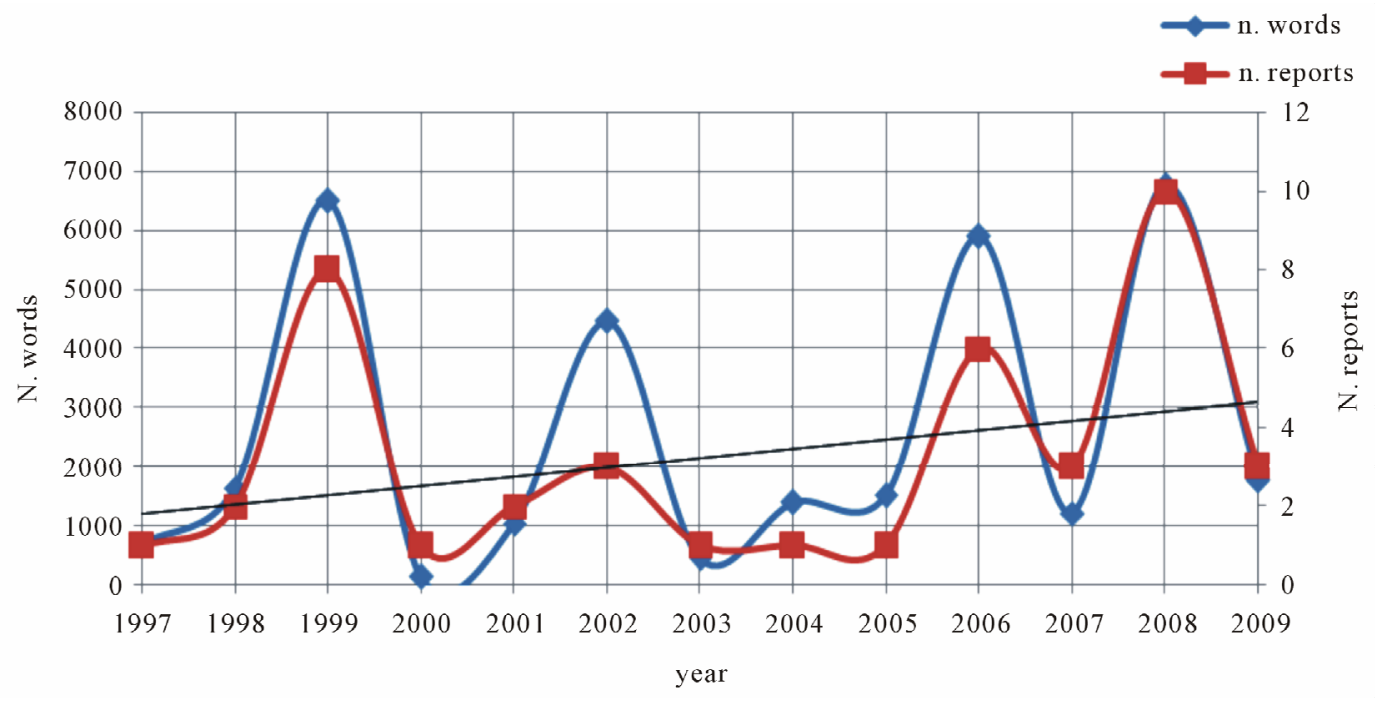

Figure 2. Records of the number of reports published in the newspapers TGM and TNP, per year, regarding bottled water.

The population of a town in a rural area in Australia proclaimed the suppression of the bottled water commercial trade due to its high cost to the environment and residents of the town of Bundanoon began to encourage visitors to fill reusable bottles in drinking fountains on the city's main street. The local mayor was very proud of it, because this was the first city in the world to prevent their shop owners from selling bottled water [50].

Therefore, it is possible to remark that attitudes for the promotion of tap water exist not only in Canada but around the world and media has played a vital role as a channel of information for the public.

\subsubsection{CI $2^{-}$Consumption of Bottled Water}

"Now use bottled water at home, toward deemed one of capitalism's great mysteries-the packaging and selling of something already available to us free. Our socialized consumerism teamed with canny advertising and conspired to create a climate where we dutifully shell out for overpriced branded water that's not always better than the stuff coming out of our own taps."

In Silva [51] it is seen that the consumption of bottled water reflects a kind of lifestyle. A change in the lifestyle of people is linked to the phenomenon of urbanization. The urbanization gives people, due to all kinds of new technologies, a range of options for the consumption of different types of products, which have contributed to the environmental degradation from the exploitation of raw materials to final consumption.

Consumption is motivated, first and foremost, by the need of social groups to achieve distinction and recognized status. Consumption as a place of differentiation and distinction between classes and groups, has called attention to the aesthetic and symbolic aspects of consumer rationality. There is logic in the construction of the tokens of status and in the ways of communicating them. In contemporary society, much of the rationality of social relations is constructed, rather than the struggle for the means of production, competition for ownership of the means of symbolic distinction. Products are often used as status symbols to communicate the real or desired social class [52].

Royte [53] answers the question: why consume bottled water? A combination of marketing, fashion, capitalism, and cultural, economic, political and hydrological trends answers the question. The author believes that the consumption of bottled water appeared as a fashion trend starting from the "yuppies", because it used to be "cool" to walk around with a famous branded bottle in one hand. It was the '70 s and ' $80 \mathrm{~s}$ and there were small companies in Europe ready to meet and increase this demand of being "chic". But once the habit of a few became fashionable for millions, major corporations entered this market. It had begun a process, which would have profound socioeconomic and environmental consequences. The pendulum swung and bottled water took on a new symbolism: consumers splurge, disregard for tap water and environmental hazard.

Flecker [54] raises the question of adding salts, vitamins and flavors as devices used to gain and maintain customer loyalty. The marketing of bottled water combines health to fitness, conveying that it doesn't make people fat, it hydrates, etc. Nevertheless, the author notes that 30 million bottles are discarded in landfills every day in Canada and only 13\% are recycled. Filling plants are inspected once every four or five years. Plastic containers consume fossil fuel, releasing toxic contaminants that can affect the nervous system, the kidneys, cause cancer and problems of formation in fetuses.

The world market is perceived as some sort of alien 
force. The consumer does not dominate or control it, but is dominated and controlled by it in the process of fetishism-in which people lose control of the use of their lives. Values related to the citizens disappear-summarized in the notion of human dignity - now converted into a manager or consumer. Thus, the automated individual from a mass society knows the price of all things, but do not know his/her own value. The economy is presented as the only way of thinking and being. History is history made by the economy and not by people; is the story of the goods and world market [55].

\subsubsection{CI $3^{-}$It Is Time to Go Back to Tap Water}

"Critics say the costs of packaging and transporting bottled water puts a strain on the environment, and also raises ethical concerns about the use of Canada's water resources. The municipal water supplies are being drained in the name of bottling local water, and local ecosystems are harmed in the process. Municipalities are right to be concerned about the environmental implications of an industry that consumes seven litres of water to produce a single plastic one-litre bottle. There have been 27 recalls of bottled water by the Canadian Food Inspection agency since 2000 . The bottled water generates controversy because of the perceived commodification of water by corporations who charge a huge premium for what is often not much more than filtered tap water. In fact, two of the most popular brands use water from municipal water supplies in Canada.”

The bottling of water, a deal that may seem innocent, has far reaching consequences for everyone: costs, damages and environmental conflicts, poor quality control, over-exploitation of aquifers, production of inputs such as resin for plastic packaging and its waste, and the transportation of packaged products as also discussed by Barlow and Clarke [34] Bouguerra [36].

Another problem is highlighted by the Worldwatch Institute [56], the Container Recycling Institute reports that sales of virgin resin (polyethylene terephthalate-PET), the most widely used material in plastic water bottles, went up to 738 million pounds in 1999, more than double the volume produced in 1990. The production of $1 \mathrm{~kg}$ of PET plastic requires 17.5 liters of water and results in atmospheric emissions of 40 grams of hydrocarbons, 25 grams of sulfur oxides, 18 grams of carbon monoxide, 20 grams of nitrogen oxide and $2.3 \mathrm{~kg}$ of carbon dioxide. In terms of water use, the amount spent on manufacturing the bottles is many times greater than the amount to be bottled. Recalling that the plastic is made from oil and natural gas, both nonrenewable resources.

Regarding distribution, in contrast to tap water, bottled water involves burning fossil fuels in transport by truck, rail or ship, instead of pipes. This situation is worsened when one observes that $25 \%$ of all bottled water is mar- keted and consumed outside the country of production [34]. Emissions of carbon sources responsible for the greenhouse gases and sulfur dioxide, resulting from transport of bottled water within and between countries, contributes to the problem of global climate change.

Bullers [57] points out that, according to the IBWA, North Americans consumed 5 billion gallons of bottled water in 2001, which means the same amount of water that pours from Niagara Falls every two hours. It is argued that tap water is safe because it undergoes rigid quality standards by the responsible agencies, which are warned in an efficient time frame when and if problems occur. It also highlights the benefits for oral health related to the fluoride added to tap water mainly for people aged between 7 and 16 years old. Young people who were brought up consuming bottled water have a certain resistance to consuming tap water, due to the appeal of bottled water to provide quality health and wellness. Consumers may buy purified bottled water originated from tap water, but also may choose to purchase filters for the consumption of tap water.

In another study Bouchez [58], states that $71 \%$ of North Americans who answered his survey, reported that bottled water is better than tap water. The author notes, however, studies, which show that if they tested a 100 different brands of bottled water, $30 \%$ will show some kind of problem, a number similar to tests performed with tap water. If there are few differences in quality requirements of water why does the consumer choose to spend more? Experts argue that people's needs are different. They say people should be given the power of choice. And that some minerals are needed to maintain health, so consumption should be according to personal needs and an alert should be issued about reading the label on the packaging before purchasing it. Many foods are also rich in minerals; so bottled water should not be the only choice as a source of them. Flavor is also a factor in the choice between tap and bottled water, and even among different brands of bottled water. The study also questions the environmental impacts of plastic bottles (for producing them the oil consumption is " 1.5 million barrels per year in the U.S., which is equivalent to the consumption of 100,000 cars" and disposal at landfill sites - $86 \%$ of the total intake) and risks to health from the compounds which can be dissolved in the water. Finally, the author addresses studies that warn about cancer risks associated with the components of plastic bottles.

\subsubsection{4- Use Bottled in Special Cases}

"Health officials said tap water is unsafe for drinking after the risk of bacteria, viruses and chemical infecting the water supply. The population is told to use only bottled or boiled water."

The population searches frantically in stores and au- 
thorities provide bottled water in very special cases, such as the occurrence of chemical and bacteriological contamination of tap water. Nonetheless, production and marketing of bottled water are at such an increasing rate. Evidently, the replacement of bottled water for everyday use will require the consolidation of confidence in public water supply, a solution that can be feasible to provide safe and sustainable sources of water. That demands, however, especially in less developed countries, political will and effective public policies.

The recognition of water as a fundamental human right implies holding governments accountable for ensuring access to water for all people, without distinction, on a non-profit basis. Nevertheless, the interests of large corporations, which operate within the trade of water, work against this right. Water is recognized as a necessity to be provided by private initiative and absorbed by the market logic $[5,34-36,44,45]$.

\subsubsection{CI $5^{-}$Major Bottled Water Corporations}

"The world's top sellers of bottled water are trying to stop Western consumers from turning back to the tap trumpeting health benefits and there are going fights between communities around the Great Lakes and bottled-water companies."

Canada allows the exploitation of 30 billion gallons of water per year for bottling. The country exports $90 \%$ of these bottled waters to the United States and the rest to Japan, UK and Taiwan [30].

Clarke [35] warns about some strategies of large bottled water corporations that have exclusive contracts with schools, colleges and universities in the United States and Canada. These contracts provide high profits and cause students to be consumers of their products on an exclusive basis, because competitors are excluded. Marketers of these companies argue that people aged 6 to 24 years old are likely to be large consumers of their products for 50 or 60 years, ensuring the company's business for the future.

Some examples from around the world can be given as Barlow tells us [44] in Chiapas in Mexico a transnational company benefitted from the granting of zoning laws favorable to extract enough water to cover five villages while the inhabitants were left without water and supplements-some of these licenses are valid until 2050. Accusations of foul smells were pinpointed in the same transnational company in the Philippines, where 500 families have accused the company of launching harmful contaminants in their water supply. The Ogallala aquifer, one of the biggest in the world, supplies a fifth of all irrigated land in United States and it spreads over eight U.S. states, currently has its water removed at a rate that imposes a speed ten times higher than the capacity of natural replenishment of the aquifer.
In many Indian states, the rate of extraction of groundwater is so high that water tables fall from one to three meters per year. In Tamil Nadul, water tables have fallen almost thirty feet since the 1960s. In the district of Pallakad, Kerala, the extraction of groundwater by a transnational company depleted the aquifer; many wells dried up and caused severe damage to the environment. The episode repeated itself on the outskirts of Bombay, the same company provoked protests by farmers against their operations in water extraction to serve the bottled water market for a rapidly growing middle class. The states of Gujarat and Rajasthan have also witnessed repeated disruption of violent conflicts related to water use [46].

In Brazil, there are social conflicts in the southern part of Minas Gerais state between a large transnational and a sanitation company which bottles mineral water. The place is called the Water Circuit of Minas Gerais, having sources of mineral waters, which are considered the most diverse on the planet.

There is an international oligarchy of water, which is privatizing and commodifying water around the planet and this phenomenon has increased in recent years, assuming different forms. This oligarchy produces knowledge, gives a specific direction to public speeches, has a narrative power, influences the media and determines a global water agenda [59]. Caubet [60], Chenais and Sefati [61] emphasize that commercialization, privatization, deregulation and renormalization of this market as well as various forms of relocation, are the characteristics of the policy advocated by the international "owners" of waters, which consider the water as a new frontier of making profits.

\subsubsection{CI $6^{-}$Use Bottled Water Is Better than Tap Water}

"The adding chlorine to municipal water supplies form compounds called trihalomethanes-THMs and longterm exposure to high levels may be associated with cancer. Use bottled water is better."

It is pertinent to expose that according to Rahman et al. [62] the THMs are not carcinogenic at recommended doses for use in drinking water and chlorination disinfection by-product-DBP, may have an association with an increased risk of colorectal cancer. However, the authors point out that a small number of relevant studies have important methodological limitations.

However, studies show that toxic elements can break off the plastic casing and cause acute and chronic damage to people's health. An example is the presence of antimony in PET bottles. Shotyk et al. [23] presented a study where they used 15 samples of bottled water from Canada and 48 samples from Europe. Some issues were raised, as whether is the relationship between the concentration of antimony in the polymer and the release 
rate in the bottled water relevant. Since this varies depending on $\mathrm{pH}$ levels, temperature, presence of other cations and anions, storage conditions and reaction time, the authors suspect that contamination by antimony is more widespread than we imagine. It is noted that PET is not only used for bottled water, but in drinks, food packaging and pharmaceuticals.

Shotyk and Krachler [15] studied the contamination of bottled waters with antimony lixiviation in PET bottles, increasing its storage time. The antimony concentration was determined in 132 brands from 28 countries. 14 brands in Canada had it increased by $19 \%$ over a storage time of six months. 48 brands from 11 countries of Europe had a $90 \%$ increase in the concentration of antimony under identical conditions of storage.

One of the biggest problems the bottled water industry faces is plastic waste. According to the Container Recycling Institute, about 14 billion water bottles were sold in the United States in 2002, 90\% of which were discarded in the environment, even though most of them have been made with recycled PET plastic. Most plastic bottles are not being recycled and rapidly accumulate in landfills or are simply are discarded in the environment around the world. Considering that plastic decomposes at very low speeds, they will remain with us for over hundreds of years since burn them is dangerous. Incineration produces toxic byproducts such as dioxins of chlorine and heavy metals in their ashes [56].

\section{Concluding Remarks}

Studies and research on the subject of increasing consumption of bottled waters and their implications are needed to assist with information that can serve as a basis for implementing policies in order to improve water supply coming from public networks. Also contributing to investments that promote user confidence in consuming water from the tap is important.

It should be stressed here that, as the Human Development Reports of the United Nations Development Programme points out, over 1 billion people around the world, especially in the so-called "developing countries", have no access to drinking water. Drinking water is a fundamental human right and it is at the heart of a daily crisis affecting several millions of vulnerable people in the world. The preservation of the human right to drinking water is an end in itself and a means of representing one of the more general rights in the Universal Declaration of Human Rights as well as in other instruments with legal links, including the right to life, education, health and housing [46].

People have the right to receive high quality water from the tap and governments need to put this into practice with effective actions that will provide the popula- tion with important information such as public policies aimed at ensuring the health of the population without the prevailing of economic interests. It is noted here that efficient mechanisms should be used to enable dialogue, increase awareness and promote confidence in the quality of the water supplied, providing the public with better conditions for a conscious decision-making so the population can know what kind of water should be consumed and what kind of social and environmental impacts their decision might entail.

It was observed that the selected print media presented a range of news reports that provided the reader with thoughts on the current situation of water supply in Canada. The media has been feeding the population with important warnings such as to boil water when consuming it to reduce risk to their health. News reports also present news alerts and complaints.

The Discourse Collective Subject, inspired by the theory of social representation, provided an approximation to the speeches on tap water and bottled water circulating as news reports in Canadian newspapers. It was felt that the information passed to the population was actually confusing and influenced the pattern of consumption, because of its ambiguous nature. However, this same channel that mixes influences and allows reflection may stimulate research on the subject matter of drinking water.

Canada is a privileged country in relation to their water resources and concerns to society, including government, general public, academia, media professionals, working to ensure that the commodification of water will not endanger the basic right to have safe water for all people.

This study does not intend to exhaust this subject, however it seeks to support it with a better understanding of the current situation in order to also underpin future studies.

\section{Acknowledgements}

Authors are thankful to Queen's University and Federal University of Minas Gerais providing the opportunity to develop this research in partnership. Authors are also thankful to the The National Councel for Technological and Scientific Development (CNPq) from Brazil for the financial assistance to carry out this work granting a scholarship to the first author.

\section{REFERENCES}

[1] P. Levallois, J. Grondin and S. Gingras, "Evaluation of Consumer Attitudes on Taste and Tap Water Alternatives in Quebec," Water Science and Technology, Vol. 40, No. 6, 1999, pp. 135-139.

doi:10.1016/S0273-1223(99)00549-1 
[2] E. C. Anadu and A. K.Harding, "Risk Perception and Bottled Water Use," Journal American Water Works Association, Vol. 92, No. 11, 2000, pp. 82-96.

[3] B. A. Larson and E. D. Gnedenko, "Avoiding Health Risks from Drinking Water in Moscow: An Empirical Analysis," Environment and Development Economic, Vol. 4, No. 4, 1999, pp. 565-581. doi:10.1017/S1355770X99000339

[4] C. Ferrier, "Bottled Water: Understanding a Social Phenomenon," AMBIO: A Journal of the Human Environment, Vol. 30, No. 2, 2004, pp. 118-119.

[5] P. H. Gleick and H. S. Cooley, "Energy Implications of Bottled Water," Environmental Research Letters, Vol. 4, No. 1, 2009, pp. 1-6. doi:10.1088/1748-9326/4/1/014009

[6] Y. Parag and J. T. Roberts, “A Battle Against the Bottles: Building, Claiming, and Regaining Tap-Water Trustworthiness," Society \& Natural Resources, Vol. 22, No. 7, 2009, pp. 625-636. doi:10.1080/08941920802017248

[7] Statistics Canada, "Households and the Environment," 2006. http://www.statcan.gc.ca/

[8] A. Q. Jones, C. E. Dewey, K. Dore, S. E. Majowicz, S. A. McEwen and D. Waltner-Toews, "A Qualitative Exploration of the Public Perception of Municipal Drinking Water," Water Policy, Vol. 9, No. 4, 2007, pp. 425-438. doi:10.2166/wp.2007.019

[9] K. D. M. Pintar, D. Waltner-Toews, D. Charron, F. Pollari, A. Fazil and S. A. McEwen, "Water Consumption Habits of a South-Western Ontario Community," Journal of Water and Health, Vol. 7, No. 2, 2009, pp. 276-292. doi:10.2166/wh.2009.038

[10] F. Doria, "Bottled Water Versus Tap Water: Understanding Consumers' Preferences,” Journal of Water and Health, Vol. 4, No. 2, 2006, pp. 271-276.

[11] L. Ward, O. Cain, R. Mullally, K. Holliday, A. Wernham and P. Baillie, "Health Beliefs about Bottled Water: A Qualitative Study,” BMC Public Health, Vol. 9, No. 1, 2009, pp. 196-210. doi:10.1186/1471-2458-9-196

[12] L. Fewtrell, D. Kay, M. Wyer, A. Godfree and G. Oneill, "Microbiological Quality of Bottled Water," Water Science and Technology, Vol. 35, No. 11-12, 1997, pp. 47-53. doi:10.1016/S0273-1223(97)00233-3

[13] I. Al-Saleh and I. Al-Doush, "Survey of Trace Elements in Household and Bottled Drinking Water Samples Collected in Riyadh, Saudi Arabia,” The Science of The Total Environment, Vol. 216, No. 3, 1998, pp.181-192. doi:10.1016/S0048-9697(98)00137-5

[14] P. Garzon and M. J. Eisenberg, "Variation in the Mineral Content of Commercially Available Bottled Waters: Implications for Health and Disease," The American Journal of Medicine, Vol. 105, No. 2, 1998, pp. 125-30. doi:10.1016/S0002-9343(98)00189-2

[15] W. Shotyk and M. Krachler, "Contamination of Bottled Waters with Antimony Leaching from Polyethylene Terephthalate (PET) Increases upon Storage,” Environmental Science and Technology, Vol. 41, No. 5, 2007, pp. 15601563. doi:10.1021/es061511+

[16] R. Ramalho, J. Cunha, P. Teixeira and P. A. Gibbs, "Improved Methods for the Enumeration of Heterotrophic Bacteria in Bottled Mineral Waters," Journal of Micro- biological Methods, Vol. 44, No. 2, 2001, pp. 97-103. doi:10.1016/S0167-7012(00)00237-2

[17] A. Ikem, S. Odueyungbo, N. O. Egiebor and K. Nyavor, "Chemical Quality of Bottled Waters from Three Cities in Eastern Alabama,” The Science of The Total Environment, Vol. 285, No. 1-3, 2002, pp.165-175. doi:10.1016/S0048-9697(01)00915-9

[18] F. A. Rosenberg, “The Microbiology of Bottled Water," Clinical Microbiology Newsletter, Vol. 25, No. 6, 2003, pp. 41-44. doi:10.1016/S0196-4399(03)80019-3

[19] F. Zohouri, A. Maguire and P. Moynihan, "Fluoride Content of Still Bottled Waters Available in the North-East of England, UK,” British Dental Journal, Vol. 195, No. 9, 2003, pp. 515-518. doi:10.1038/sj.bdj.4810668

[20] S. D. Raj, “Bottled Water: How Safe Is It?” Water Environment Research, Vol. 77, No. 7, 2005, pp. 3013-3018. doi:10.2175/106143005X73893

[21] M. L. Jeena, P. Deepa, K. M. M. Rahiman, R. T. Shanthi and A. A. M. Hatha, "Risk Assessment of Heterotrophic Bacteria from Bottled Drinking Water Sold in Indian Markets," International Journal of Hygiene and Environmental Health, Vol. 209, No. 2, 2006, pp.191-196. doi:10.1016/j.ijheh.2005.11.003

[22] R. Mahajan, T. Walia, B. Lark, Sumanjit, “Analysis of Physical and Chemical Parameters of Bottled Drinking Water," International Journal of Environmental Health Research, Vol. 16, No. 2, 2006, pp. 89-98. doi:10.1080/09603120500538184

[23] W. Shotyk, M. Krachler and B. Chen, "Contamination of Canadian and European Bottled Waters with Antimony from PET Containers," Journal of Environmental Monitoring, Vol. 8, No. 2, 2006, pp. 288-292. doi:10.1039/b517844b

[24] D. O. Scoaris, F. C. Bizerra, S. F. Yamada-Ogatta, B. A. de A. Filho, T. Ueda-Nakamura, C. V. Nakamura, et al., "The Occurrence of Aeromonas spp. in the bottled Mineral Water, Well Water and Tap Water from the Municipal Supplies,” Brazilian Archives of Biology and Technology, Vol. 51, No. 5, 2008, pp.1049-1055. doi:10.1590/S1516-89132008000500022

[25] C. Guler and M. Alpaslan, "Mineral Content of 70 Bottled Water Brands Sold on the Turkish Market: Assessment of Their Compliance with Current Regulations.” Journal of Food Composition and Analysis, Vol. 22, No. 7-8, 2009, pp. 728-737. doi:10.1016/j.jfca.2009.03.004

[26] M. Krachler and W. Shotyk, "Trace and Ultratrace Metals in Bottled Waters: Survey of Sources Worldwide and Comparison with Refillable Metal Bottles," Science of the Total Environment, Vol. 407, No. 3, 2009, pp. 1089-1096. doi:10.1016/j.scitotenv.2008.10.014

[27] M. Ahmad and A. S. Bajahlan, "Quality Comparison of Tap Water vs. Bottled Water in The Industrial City of Yanbu (Saudi Arabia),” Environmental Monitoring and Assessment, Vol. 159, No. 1-4, 2009, pp. 1-14. doi:10.1007/s10661-008-0608-8

[28] R. Holme, "Drinking Water Contamination in Walkerton, Ontario: Positive Resolutions from a Tragic Event," Water Science and Technology, Vol. 47, No. 3, 2003, pp.1-6. 
[29] K. J. Bakker, "From Public to Private to ... Mutual? Restructuring Water Supply Governance in England and Wales,” Geoforum, Vol. 34, No. 3, 2003, pp. 359-374. doi:10.1016/S0016-7185(02)00092-1

[30] C. Johns, M. Sproule-Jones and B. T. Heinmiller, "Water as a Multiple-Use Resource and Source of Political Conflict," In: M. Sproulle-Jones, C. Johns and B. T. Heinmiller, Eds., Canadian Water Politics: Conflicts and Institutions, McGillQueen's University Press, Montreal, 2008, p. 390.

[31] M. W. Rosenberg, "From East to Western Sea: Canada-A Country of National Abundance and Local Shortages,” In: J. E. Castro and L. Heller, Eds., Water and Sanitation Services: Public Policy and Management, Earthscan, London, 2009, p. 363.

[32] S. Hickman, "Tapping into Bottled Water: Carleton Examines Drinking Habits,” 2009. http://www.now.carleton.ca/2009-04/2237.htm.

[33] J. A. Marshall, "The Households and the Environment Survey,” 2009. http://www.statcan.gc.ca/

[34] M. Barlow and T. Clarke, "Blue Gold: The Fight to Stop the Corporate Theft of the World's Water," The New Press, New York, 2003.

[35] T. Clarke, "Inside the Bottle," Polaris Institute, Ottawa, 2004.

[36] M. L. Bouguerra, "Las Batallas del Agua: Por un Bien Común de la Humanidad,” Editorial Popular, Madrid, 2005.

[37] L. R. S. Moraes, “A Melhoria da Prestação dos Serviços de Abastecimento de Água em Portugal e o Aumento do Consumo de Água Envasada-Qual a Explicação?” 24 Congresso Brasileiro de Engenharia Sanitaria e Ambiental, Belo Horizonte, 2007.

[38] J. C. M. R. Silva, L. R. S. Moraes and P. C. Borja, “Comportamento da Produção e Consumo de Água Envasada em Salvador 1997-2006 e sua relação com a Água do Sistema Público de Abastecimento,” XIII SILUBESA-Simpósio Luso-Brasileiro de Engenharia Sanitária e Ambiental, Belem, 2008.

[39] J. T. M. Queiroz and L. Heller, “Que Água Devo Consumir: A do Sistema Público ou a Envasada? Percepções de Moradores de Belo Horizonte,” 25 Congresso Brasileiro de Engenharia Sanitária e Ambiental, Recife, 2009.

[40] M. F. Doria, "Factors Influencing Public Perception of Drinking Water Quality,” Water Policy, Vol. 12, No. 1, 2010, pp. 1-19. doi:10.2166/wp.2009.051

[41] I. J. Dittrich, "Retórica dos Títulos em Reportagens Impressas,” Comunicação \& Educação, Vol. 11, No. 1, 2006, pp. 20-25.

[42] F. Lefevre and A. M. C. Lefevre, "O Discurso do Sujeito Coletivo: Um Enfoque em Pesquisa Qualitativa (Desdobramentos),” EDUCS, Porto Alegre, 2003.

[43] C. Johns and K. Rasmussen, "Institutions for Water Resource Management in Canada.” In: M. Sproulle-Jones, C. Johns and B. T. Heinmiller, Eds., Canadian Water Politics: Conflicts and Institutions, McGill-Queen’s University Press, Montreal, 2008.

[44] M. Barlow, "Blue Covenant: The Global Water Crisis and the Coming Battle for the Right to Water,” The New Press, New York, 2009.

[45] V. Shiva, "Water Wars: Privatization, Pollution and Profit," South End Press, New York, 2002.

[46] United Nations Development Programme, "Human Development Report,” 2006. http:hdr/undp.org/en/reports/global/hdr2006/

[47] N. Herráiz, “Geopolítica del Agua Embotellada,” Foreign Policy Edición Española, Madrid, 2006.

[48] ALMG Assembléia Legislativa de Minas Gerais, “ONGs e Indústria Divergem Sobre Águas Minerais; Copasa Relata Ações. Reunião Audiência Pública Copasa,” 2007. http://www.almg.gov.br/not/bancodenoticias/not_623631. asp

[49] J. Lee, "City Council Shuns Bottles in Favor of Water From Tap,” 2008.

http://www.nytimes.com/2008/06/17/nyregion/17water.ht $\mathrm{ml}$

[50] BBC, “Australia Town Bans Bottled Water,” 2009. http://news.bbc.co.uk/2/hi/asia-pacific/8141569.stm

[51] S. R. Silva, "O Papel do Sujeito em Relação à Água de Consumo Humano: Um Estudo na Cidade de Vitória-ES,” Ph.D. Thesis, Universidade Federal de Minas Gerais, Belo Horizonte, 2007.

[52] P. Bourdieu, “Economia das Trocas Simbólicas,” Perspectiva, São Paulo, 2003.

[53] E. Royte, "Bottlemania: How Water Went on Sale and Why We Bought It,” Bloomsbury, London, 2008.

[54] K. Flecker, "Backlash Against Bottled Water," American Prospect, Vol. 19, No. 6, 2008, pp. 11-12.

[55] O. Matos, "Discretas Esperanças: Reflexões Filosóficas Sobre o Mundo Contemporâneo,” Editora Nova Alexandria, São Paulo, 2006.

[56] Worldwatch Institute, "State of the World 2004: Special Focus: The Consumer Society,” WWI, Washington DC, 2004.

[57] A. C. Bullers, "Bottled Water: Better than the Tap?” FDA Consumer Magazine, Vol. 4, 2002, pp. 43-46.

[58] C. Bouchez, “Is Bottled Water Better?” WebMD Weight Loss Clinic-Feature, 2004.

http://www.webmd.com/food-recipes/features/is-bottledwater-better

[59] R. Petrella, "L’eau, la Question Sociale du XXIème Siècle,” 2008. http://www.monde-diplomatique.fr/

[60] F. Chesnais and C. Sefati, "Ecologie' et Conditions Physiques de la Reproduction sociale,” In: J.-M. Harribey and M. Lowy, Eds., Capital Contre Nature. Actuel Marx Confrontation, Presses Universitaires de France, Paris, 2003.

[61] C. G. Caubet, “A Água, a Lei, a Política... e o Meio Ambiente?” Juruá Editora, Curitiba, 2005.

[62] M. B. Rahman, T. Driscoll, C. Cowie and B. K. Armstrong, "Disinfection By-Products in Drinking Water and Colorectal Cancer: A Meta-Analysis,” International Journal of Epidemiology, Vol. 39, No. 3, 2010, pp. 1-13. 